\title{
Analisis Kualitas Pertumbuhan Ekonomi Provinsi Nusa Tenggara Barat Dalam Perspektif Maqasyid Syariah
}

\author{
Muhammad Irwan, Titiek Herwanti, Muaidy Yasin \\ Ekonomi Studi Pembangunan, Fakultas ekonomi dan Bisnis Universitas Mataram
}

${ }^{*}$ Corresponding email: dae.wan65@yahoo.com

\begin{tabular}{|c|c|}
\hline Info Artikel & ABSTRAK \\
\hline $\begin{array}{l}\text { Kata Kunci: } \\
\text { Kualitas Pertumbuhan } \\
\text { Ekonomi, Kemiskinan, } \\
\text { Pengangguran, Maqashid } \\
\text { Syariah. }\end{array}$ & $\begin{array}{l}\text { Penelitian ini bertujuan mendeskripsikan dan } \\
\text { menganalisis Perkembangan dan Kualitas Pertumbuhan } \\
\text { Ekonomi Nusa Tenggara Barat tahun 2008-2018 dalam } \\
\text { Perspektif Maqashid Syariah. Pendekatan penelitian yang } \\
\text { dipergusnakan adalah penelitian deskriptif, lokasi Penelitian di } \\
\text { Nusa Tenggara Barat. Jenis data yang dipergunakan data } \\
\text { sekunder. Analisis data yang dipergunakan Analisis } \\
\text { pertumbuhan. Kualitas pertumbuhan ekonomi dalam maqasyid } \\
\text { syariah mengacu pada pemenuhan kebutuhan Daruriyah } \\
\text { Kebutuhan Pokok), dilihat dari jumlah penduduk yang masih } \\
\text { miskin, mengganggur, kriminalitas. Pemenuhan kebutuhan } \\
\text { pokok ini akan dikaitkan dengan aturan dalam Al-Qur'an dan } \\
\text { Al-Hadist. } \\
\text { Hasil penelitian menunjukkan bahwa Perkembangan } \\
\text { pertumbuhan ekonomi provinsi Nusa Tenggara Barat sejak } \\
\text { tahun 2008-2018 dilihat bahwa Rata-rata pertumbuhan ekonomi } \\
\text { berdasarkan harga konstan dengan tidak memasukkan sektor } \\
\text { tambang sebesar 5,70 persen. Nilai pertumbuhan ini masih } \\
\text { berada di bawah } 7 \text { persen sehingga dikatagorikan pertumbuhan } \\
\text { ekonomi berkualitas rendah. Rata-rata persentase penduduk } \\
\text { miskin baru mencapai 14,63 persen. Rata-rata tingkat } \\
\text { pengangguran terbuka sebesar } 5,13 \text { persen. Dimensi kebutuhan } \\
\text { dan menjaga agama, masih banyak oknum-oknum abdi negara } \\
\text { yang melakukan korupsi. Dilihat dari kebutuhan dan menjaga } \\
\text { jiwa, indikator yang digunakan adalah sikap malas. Dilihat dari } \\
\text { kebutuhan dan menjaga ilmu, kualitas manusia dilihat dari } \\
\text { Angka Melek Huruf sudah mencapai } 85 \text { persen. Kebutuhan dan } \\
\text { menjaga keturunan, pertumbuhan ekonomi belum mampu } \\
\text { sepenuhnya menurunkan angka kriminilitas, karema ada } \\
\text { masyarakat yang menggunakan narkoba dan berada dalam } \\
\text { kondisi yang sangat memprihatinkan karena akan merusak } \\
\text { keturunan (generasi) pewaris pembangunan bangsa. Dilihat dari } \\
\text { kebutuhan dan menjaga harta, pertumbuhan ekonomi belum } \\
\text { sepenuhnya mampu mewujudkan pengentasan kemiskinan }\end{array}$ \\
\hline
\end{tabular}




\section{PENDAHULUAN}

Tujuan pembangunan ekonomi adalah untuk meningkatkan jumlah dan jenis peluang kerja untuk masyarakat daerah (Arsyad, 2010). Peningkatan pertumbuhan ekonomi dari tahun ke tahun dan tergolong berkualitas akan memberikan dampak pada kualitas kinerja sektor-sektor lainnya baik dalam pemerintahan maupun swasta. Oleh karenanya, pertumbuhan ekonomi berkualitas sangat bergantung pada kondisi perekonomian nasional maupun global. Pemerintah terus melakukan perencanaan yang matang dengan berbagai kebijakan untuk mencapai pertumbuhan ekonomi yang berkualitas.

Pemerintah Provinsi Nusa Tenggara Barat tengah dan telah berikhtiar secara maksimal untuk melaksanakan pembangunan ekonomi, dengan terus meningkatkan laju pertumbuhan ekonomi setiap tahun. Hal tersebut dimaksudkan agar proses pembangunan yang bertujuan untuk mewujudkan masyarakat beriman dan sejahtera secara perlahan dapat dipenuhi. Pemerintah Provinsi Nusa Tenggara Barat terus berupaya untuk meningkatkan kinerjanya di bidang perekonomian agar mampu menghantarkan kualitas kehidupan penduduk pada derajat yang lebih baik. Kinerja perekonomian pemerintah Provinsi Nusa Tenggara Barat dilihat dari beberapa indikator makro seperti terlihat dalam tabel berikut.

Tabel 1. Kinerja Perekonomian Pemerintah Daerah Provinsi Nusa Tenggara Barat Dilihat Dari Beberapa Indikator Makro Ekonomi Tahun 2015 - 2017.

\begin{tabular}{|l|c|c|c|}
\hline \multicolumn{1}{|c|}{ Indikator } & \multicolumn{3}{c|}{ Tahun } \\
\cline { 2 - 4 } & $\mathbf{2 0 1 5}$ & $\mathbf{2 0 1 6}$ & $\mathbf{2 0 1 7}$ \\
\hline $\begin{array}{l}\text { Pertumbuhan Ekonomi } \\
\text { ADHK 2010 Tidak Termasuk Sektor Tambang (\%) }\end{array}$ & 5,02 & 5,71 & 7,10 \\
\hline Kemiskinan (\%) ( September) & 16,54 & 16,02 & 15,05 \\
\hline Pengangguran Terbuka (\%) & 5,69 & 3,94 & 3,32 \\
\hline
\end{tabular}

Sumber : BPS- NTB, 2018

Pertumbuhan ekonomi menunjukkan arah positif dari tahun ketahunnya, dibarengi dengan kemiskinan dan Tingkat Pengangguran Terbuka (TPT) yang menurun selayaknya dapat meningkatkan kesejahteraan penduduk terutama berkenaan dengan peluang dan kesempatan untuk meraih kerja. Sumber daya manusia sebagai pelaku utama aktivitas ekonomi harus memperoleh ruang dan kesempatan yang luas dan memiliki hak yang untuk memperoleh pekerjaan sebagai sumber pendapatan untuk memenuhi kebutuhan hidup diri dan keluarganya. Bila hal ini belum dan tidak tercapai, meskipun pertumbuhan ekonomi tinggi tetap tergolong sebagai pertumbuhan ekonomi yang tidak berkualitas.
Pertumbuhan ekonomi berkualitas merupakan pertumbuhan ekonomi yang mampu memberikan ruang untuk meningkatnya jumlah lapangan kerja yang berimplikasi menurunnya jumlah pengangguran. Menurut Arsyad (2010) pertumbuhan ekonomi berkualitas adalah pertumbuhan ekonomi yang mampu menyediakan kesempatan kerja yang cukup besar yaitu pertumbuhan ekonomi yang dipicu oleh banyaknya investasi yang bersifat padat karya atau padat tenaga kerja bukan yang bersifat padat modal. Berdasarkan indikator ini maka layak dipertanyakan, pertumbuhan ekonomi yang terjadi pada skala nasional maupun regional termasuk di provinsi Nusa Tenggara Barat yang selalu mengalami 


\section{Elastisitas - Jurnal Ekonomi Pembangunan \\ Vol. 2 No. 2, September 2020}

peningkatan tergolong berkualitas atau tidak berkualitas.

Tujuan hakiki kehidupan manusia di dunia selain beribadah kepada Tuhannya, juga untuk mencapai kebahagian dan kesejahteraan hidup baik di dunia maupun di akhirat (al-falah). Ekonomi Islam menempatkan secara bersamaan aspek material dan spritual dijadikan indikator kemajuan pembangunan ekonomi dan kesejahteraan suatu bangsa maupun daerah. Kesejahteraan (al-falah) dapat terwujud bila mampu memenuhi berbagai kebutuhan manusia secara seimbang yang berdampak tercapainya maslahah. Kebutuhan - kebutuhan pokok manusia yang harus dijaga, terhimpun dalam tujuan syariah (maqashid syariah), yaitu menjaga agama, menjaga jiwa, menjaga akal, menjaga keturunan dan menjaga harta. Apa saja yang menjamin terlindungnya, 5 perkara ini adalah memenuhi kepentingan publik dan dianjurkan, dan apa saja yang mencederai 5 perkara ini adalah melawan kepentingan publik yang harus dibuang (Chapra, 2011).

Islam yang menjadi landasan operasional utama ekonomi Islam telah memberikan petunjuk agar manusia meningkatkan kualitas kehidupannya. Kualitas kehidupan yang baik menurut Islam mampu memenuhi kebutuhan pokok sekaligus menjaga dan memeliharanya. Untuk mewujudkannya, manusia diperintahkan wajib melakukan berbagai aktivitas bekerja sesuai dengan kadar kemampuan serta keahlian yang dimilikinya. Islam juga memberi petunjuk bahwa manusia dapat merealisasikan aktivitasnya bila dibarengi dengan kepemilikan pengetahuan yang memadai. Oleh karenanya Islam mewajibkan untuk menuntut ilmu agar memiliki derajat yang lebih baik dibanding dengan orang yang tidalk memiliki ilmu pengetahuan.

Penekanan Islam untuk mewajibkan bekerja agar manusia tidak mengotori jiwanya dengan sikap malas dan tidak mau bekerja dan lebih baik menganggur. Menganggur merupakan suatu tindakan manusia yang sangat dibenci oleh Islam, karena potensi yang ada di dalam setiap diri manusia tidak dimanfaatkan untuk memperoleh penghasilan. Menganggur mengakibatkan tidak terjadinya sirkulasi barang dan jasa sehingga tidak memberikan penghasilan dan pendapatan. Padahal penghasilan dan pendapatan merupakan sumber untuk memperoleh kebutuhan hidup yang tidak dapat diproduksinya sendiri. Dampak dari pengangguran ini bermuara pada peningkatan jumlah penduduk miskin, suatu kondisi yang sangat mendapat perhatian Islam untuk dipecahkan.

Pertumbuhan ekonomi yang tinggi dan tergolong berkualitas merupakan harapan dari setiap pemerintah daerah, termasuk Provinsi Nusa Tenggara Barat. Banyak dampak positif yang ditimbulkan oleh pertumbuhan ekonomi yang tinggi dan berkualitas, tidak hanya berdimensi material duniawi namun mencakup aspek spritual dan ukhrawi. Oleh karenanya penelitian ini dilaksanakan untuk menggambarkan, mendeskripsikan sekaligus menganalisis kualitas pertumbuhan ekonomi provinsi Nusa Tenggara Barat beserta beberapa indikatornya sekaligus melihat dari aspek spritual ukhrawi untuk mencapai kesejahteraan duniawi dan ukhrari sesuai dengan Maqashid Syariah atau Tujuan Syariah.

Eko Prasetyo (2008) mengatakan bahwa pertumbuhan ekonomi di Indonesia selama ini cukup tinggi, tetapi belum berkualitas, karena secara riil pertumbuhan ekonomi tersebut belum mampu mengurangi tingkat pengangguran dan kemiskinan. Dengan adanya pertumbuhan ekonomi yang berkualitas diharapkan mampu mengurangi pengangguran dan kemiskinan. Stamboel (2012) mengatakan bahwa pertumbuhan ekonomi pada tahun 2010 sebesar $6,10 \%$ dan pada tahun 2011 sebesar $65 \%$ dikatagorikan berkualitas rendah. Beberapa aspek yang dilihat adalah mulai dari aspek ekonomi, kesehatan dan pendidikan. Yang paling kentara dari 
rendahnya kualitas pertumbuhan ekonomi Indonesia adalah ketimpangan pembangunan, kontribusi pertumbuhan antar wilayah juga belum ideal dan perbaikannya juga belum signifikan. Pertumbuhan ekonomi yang berkualitas dan inklusif akan menjadi landasan penting bagi pengentasan kemiskinan dan akan bermanfaat bagi masyarakat miskin untuk mendorong peningkatan pendapatan dan distribusinya.

Antara (2012) dalam kajiannya menyatakan bahwa Pemerintah perlu mewaspadai tren penurunan daya serap perekonomian terhadap penciptaan lapangan kerja. Sebelumnya, setiap pertumbuhan ekonomi 1\% mampu menyerap 400-500 ribu tenaga kerja. Faktanya, 1\% pertumbuhan ekonomi 2011 hanya menampung 225 ribu tenaga kerja. Artinya, daya serap ekonomi hanya separuh dari target pemerintah. Dalam APBNP 2012, pemerintah mematok setiap $1 \%$ pertumbuhan mampu menyerap 450 ribu tenaga kerja baru. Kenyataan tersebut kian membuktikan bahwa pertumbuhan ekonomi nasional belum berkualitas. Selama ini, sektor yang berbasis padat modal masih menjadi kontributor utama produk domestik bruto (PDB). Saat ini, sector pengangkutan dan komunikasi menyumbang 10,48\% PDB, sektor konstruksi $(7,98 \%)$, dan sektor keuangan, real estat, jasa perusahaan $(7,41 \%)$. Sebaliknya, pertumbuhan sektor manufaktur dan industri pengolahan melambat.

Pertumbuhan ekonomi adalah kenaikan Gross Domestic Produk (GDP) atau Gross National Product (GNP) tanpa memandang apakah kenaikan itu lebih besar atau lebih kecil dari tingkat pertumbuhan penduduk, dan apakah terjadi perubahan struktur ekonomi atau perbaikan sistem kelembagaan atau tidak (Arsyad, 2010). Menurut Todaro dan Stephen C. Smith (2006) dalam Badrudin (2012), pertumbuhan ekonomi adalah ilmu yang mempelajari peningkatan produksi barang dan jasa dalam kegiatan ekonomi masyarakat. Peningkatan Produksi barang dan jasa berkaitan dengan efisiensi, alokasi biaya minimum dari keterbatasan sumber daya, dan pertumbuhan optimal dari sumber daya. Menurut Kuncoro (2010) pertumbuhan ekonomi adalah ilmu yang mempelajari peningkatan produksi barang dan jasa secara nasional. Pertumbuhan ekonomi merupakan syarat yang diperlukan (necessary) tetapi tidak mencukupi(sufficient) bagi proses pembangunan ekonomi.

Pertumbuhan ekonomi yang tinggi merupakan suatu kesuksusan yang diraih oleh suatu negara maupun daerah dalam menjalankan roda perekonomian. Pertumbuhan ekonomi yang tinggi harus disertai dengan pertumbuhan ekonomi yang berkualitas. Pertumbuhan ekonomi yang berkualitas dengan memperhitungkan pemerataan pendapatan serta pengentasan kemiskinan dan pengangguran (Prasetyo, 2008). Selain itu, pertumbuhan ekonomi semakin berkualitas ketika semakin besar masyarakat yang terlibat dan menikmati hasil ekonomi produktif di dalam sistem perekonomian (Firmanzah, 2014). Darmin Nasution (2017) mengatakan Pertumbuhan yang berkualitas sebenarnya yang tidak perlu tinggi tapi tingkat pengangguran turun, kemiskinan turun, gini ratio turun, inflasi turun. Ia mengatakan nilai penting dalam pertumbuhan ekonomi adalah indikator pengagguran yang menurun dan tingkat kemiskinan yang juga turun. Menurut Stamboel (2012) pertumbuhan ekonomi dapat dikatakan berkualitas rendah apabila besarnya kurang dari 7 persen, adanya ketimpangan pembangunan, kontribusi pertumbuhan antar wilayah ideal, penurunan jumlah pengangguran masih lebih kecil yang tidak sesuai dengan target yang telah ditetapkan. Pertumbuhan ekonomi masih ditopang oleh sektornon tradeable yang kurang dapat menyerap tenaga kerja.

Pertumbuhan ekonomi dalam islam bukan hanya aktivitas produksi semata, namun merupakan aktivitas yang 
menyeluruh dalam bidang produksi yang berkaitan erat dengan keadilan distribusi (Huda, dkk, 2015). Perhatian Islam terhadap permasalahan ekonomi sekaligus pertumbuhan ekonomi jauh lebih dahulu sebelum sistem kapitalisme dan Marxisme yang dikembangkan di dunia barat. Pemikir - pemikir ekonomi Islam telah memberikan kontribusi besar terhadap permasalahan ekonomi sekaligus pertumbuhannya dengan melihat aspek material dan spritual. Menurut Chapra (2010), pengabaian terhadap pemenuhan kebutuhan material dan spritual, akan menggalkan realisasi kesejahteraan sejati dan akan memunculkan simptom anomei seperti frustrasi, kriminal, alkoholisme, ketagihan obat terlarang, perceraian, sakit mental dan bunuh diri, di mana kesemua itu mengindikasikan adanya kekurangan kedamaian batin dalam setiap individu. Menurut Tariqi (2004) dalam Huda (2015) bahwa karak-teristik pertumbuhan ekonomi Islam adalah : (a) Serba meliput, (b). Berimbang, (c) Realistis, (d) Keadilan, (e) Bertanggung Jawab. yaitu : Tanggung jawab antara sebagian anggota masyarakat dan sebagian golongan lainnya. Dan Tanggung jawab negara terhadap masyarakat, (f) Mencukupi dan (g) Berfokus Kepada Manusia.

Maqashid syariah yang diungkapkan oleh para ulama terdahulu yaitu ( Fauzia, dkk, 2014). Al-Ghazali mengatakan, secara terminologi maqashid syariah adalah penjagaan terhadap maksud dan tujuan syariah adalah upaya mendasar untuk bertahan hidup, menahan faktor-faktor kerusakan dan mendorong terjadinya kesejahteraan. Al-Qardhawi mendefinisikan maqashid syariah sebagai tujuan yang menjadi target teks dan hukum-hukum partikular untuk direalisasikan dalam kehidupan manusia, baik berupa perintah, larangan dan mubah, untuk individu, keluarga, jemaah dan umat, atau juga disebut dengan hikmah yang menjadi tujuan ditetapkannya hukum, baik yang diharuskan ataupun tidak.
Maksud dan tujuan dari maqashid syariah adalah mewujudkan kemaslahatan manusia di dunia dan akhirat. Maslahah dasar bagi kehidupan manusia menurut AsShatibi terdiri dari lima hal yaitu agama (dien), jiwa (nahs), Akal (aql), keturunan/keluarga (nasl), dan harta (mal). Menurut Asy- Syatibi bahwa tujuan utama dari maqasid syariah adalah untuk menjaga dan memperjuangkan tiga katagori hukum antara lain : (a) Daruriyyat, berarti kebutuhan yang mendesak atau darurat. Dalam katagori ini ada lima hal yang perlu diperhatikan yaitu memelihara agama, memelihara jiwa, memelihara akal pikiran, memelihara kehormatan dan keturunan serta memelihara harta benda. Dalam kebutuhan Daruriyyat, apabila tingkat kebutuhan ini tidak terpenuhi, maka akan mengancam keselamatan umat manusia di dunia maupun di akhirat. (b) Hajiyyat, berartti kebutuhan sekunder. Apabila kebutuhan ini tidak terwujud tidak sampai mengancam keselamatan, namun akam mengalami kesulitan. Untuk menghilangkan kesulitan tersebut, dalam islam terdapat hukum rukhsa (keringanan) yaitu hukum yang dibutuhkan untuk meringankan beban, sehingga hukum dapat dilaksanakan tanpa rasa tertekan dan terkekang. (c) Tahsiniyyat, berarti penyempurna. Tingkat kebutuhan ini berupa kebutuhan pelengkap. Apabila kebutuhan ini tidak terpenuhi, maka tidak akan mengancam dan tidak pula menimbulkan kesulitan.

Berdasarkan latar belakang di atas tujuan penelitian ini adalah untuk mengetahui dan menganalisis Perkembangan dan kualitas Pertumbuhan Ekonomi Provinsi Nusa Tenggara Barat Dalam Perspektif Maqashid Syariah. Penelitian ini diharapkan memberi manfaat bagi pemangku jabatan dan berbagai pihak yang tertarik dengan permasalahan pembangunan dan pertumbuhan ekonomi berkualitas khususnya yang terjadi di Provinsi Nusa Tenggara Barat. Penelitian ini dapat dijadikan landasan hipotesis untuk melakukan penelitian yang sama di 
masa mendatang terutama yang berminat dikajian Ekonomi Islam..

\section{METODE PENELITIAN}

Pendekatan penelitian yang dipergusnakan dalam penelitian ini adalah penelitian deskriptif yang mendeskripsikan dan memberikan gambaran tentang kualitas pertumbuhan ekonomi di Nusa Tenggara Barat dalam perspektif Maqshid Syariah. Hal ini dimaksudkan memberikan informasi dan gambaran yang jelas berkenaan kualitas pertumbuhan ekonomi Nusa Tenggara Barat yang terus berfluktuasi dan mengarah kepada perkembangan yang lebih baik serta dikaitkan dengan maqashid syariah. Penelitian ini dilakukan di Provinsi Nusa Tenggara Barat, dengan mengacu dan memperhatikan ketersediaan data sesuai yang dibutuhkan dalam analisis ini. Periode penilitian dilakukan selama 10 tahun yaitu dari tahun 2008 - 2018. Hal ini didasarkan pada pertimbangan kemutakhiran data serta informasiinformasi yang mengandung aspek-aspek yang dikaji dalam penelitian.

Penelitian ini sepenuhnya menggunakan data sekunder, bersumber dari berbagai instansi seperti BPS NTB, Bappeda NTB, berbagai literature dan informasi yang berkaitan dengan analisis penelitian ini. Teknik analisis yang dipergunakan adalah:

a. Analisis pertumbuhan, untuk mengetahui pertumbuhan dari setiap variabel selama priode analisis dengan rumus sebagai berikut :

a) Pertumbuhan Ekonomi berdasarkan formulasi dari Kuncoro (2013)

$$
\operatorname{Rog}=\underset{\%}{\left(\mathrm{PD}_{\mathrm{Bt}}-\mathrm{PD}_{\mathrm{Bt}-1} / \mathrm{PD}_{\mathrm{Bt}-1} \times 100\right.}
$$

Dimana : $\mathrm{PDB}_{\mathrm{t}}=$ Produk Domestik Bruto suatu negara pada tahun $\mathrm{t}$;
$\mathrm{PDB}_{\mathrm{t}-1}=$ Produk

Domestik Brotu suatu negara pada tahun $\mathrm{t}-1$

b) Formulasi dari Tambunan (2014) : $\triangle \mathrm{PDB}(\mathrm{t})=[\mathrm{PDB}(\mathrm{t})-\operatorname{PDB}(\mathrm{t}-$ 1)/PDB(t-1)] x 100

Dimana :

$\Delta \mathrm{PDB}(\mathrm{t})=$ pertumbuhan ekonomi tahun (t) tertentu dalam nilai abslout

$(\mathrm{t}-1)=$ tahun sebelumnya.

b. Tujuan utama dari Maqashid syariah mengacu pada pemenuhan 3 kebutuhan berupa Kebutuhan Daruriyah (Kebutuhan Pokok), Kebutuhan Hajiyyah (Kebutuhan Sekunder) dan Kebutuhan Tahisniyyah (Kebutuhan tersier). Kebutuhan darurriyah dapat dilihat dari jumlah penduduk yang masih miskin, mengganggur dan kriminalitas

\section{HASIL DAN PEMBAHASAN}

Perkembangan/ Kualitas Pertumbuhan Ekonomi Provinsi NTB Tahun 20082018

Pertumbuhan ekonomi merupakan salah satu variabel makro ekonomi yang dijadikan indikator untuk mengetahui baik atau tidaknya atau kinerja perekonomian suatu Negara, Provinsi maupun kabupaten/kota. Kinerja perekonomian Nusa Tenggara Barat tahun 2008 - 2018 mengalami kondisi yang berfluktuatif. Besarnya perolehan nilai PDRB baik berdasarkan harga berlaku maupun harga konstan cenderung berfluktutif dari tahun ke tahun. Analisis ini, hanya tertuju pada PDRB berdasarkan harga konstan, untuk mengetahui pendapatan riil dengan tidak memasukkan variabel inflasi. Hasil analisis berdasarkan nilai konstan akan dijadikan acuan untuk mementukan kebijakan-kebijakan berkenaan dengan pembangunan perekonomi provinsi Nusa Tenggara Barat. 
Tabel 2. Produk Domestik Regional Bruto Provinsi Nusa Tenggara Barat Tahun 2008 - 2018 berdasarkan Harga Konstan 2000 dan 2010.

\begin{tabular}{|c|c|c|c|}
\hline \multirow{2}{*}{ No } & \multirow{2}{*}{ Tahun } & \multicolumn{2}{|c|}{ PDRB (Juta Rp) } \\
\cline { 3 - 4 } & & Termasuk Tambang & Tidak Termasuk Tambang \\
\hline $\boldsymbol{1}$ & $\mathbf{2 0 0 8}$ & $\mathbf{1 6 . 8 3 1 . 6 0 0 , 8 8}$ & $\mathbf{1 3 . 4 0 0 . 0 3 2 , 3 3}$ \\
\hline $\mathbf{2}$ & $\mathbf{2 0 0 9}$ & $\mathbf{1 8 . 8 7 4 . 4 0 3 , 5 2}$ & $\mathbf{1 4 . 4 1 3 . 0 9 9 , 2 5}$ \\
\hline 3 & 2010 & $70.122 .726,00$ & $51.405 .721,00$ \\
\hline 4 & 2011 & $67.379 .140,58$ & $54.511 .957,78$ \\
\hline 5 & 2012 & $66.340 .812,44$ & $57.521 .371,74$ \\
\hline 6 & 2013 & $69.766 .714,11$ & $60.640 .342,61$ \\
\hline 7 & 2014 & $73.372 .963,80$ & $64.448 .556,13$ \\
\hline 8 & 2015 & $89.337 .985,80$ & $68.632 .534,12$ \\
\hline 9 & 2016 & 94.537 .748 .78 & $72.728 .519,85$ \\
\hline 10 & 2017 & $94.644 .993,20^{*}$ & $77.888 .661,24^{*}$ \\
\hline 11 & 2018 & $90.323 .419,50^{* *}$ & $80.285 .612,34^{* *}$ \\
\hline
\end{tabular}

Sumber : BPS NTB, BAPPEDA NTB. ${ }^{*}$ ) angka sementara: ${ }^{* *}$ ) angka sangat sementara

PDRB provinsi Nusa Tenggara Barat tanpa tambang menunjukkan kondisi yang konsisten terus mengalami peningkatan. Sejak tahun 2010-2018 peningkatan PDRB berkisar Rp 3-5 trilyun dengan peningkatan tertinggi pada tahun 2017 dan terendah pada tahun 2018. Rata-rata peningkatan PDRB dari tahun 2010-2018 sebesar Rp 3.208.876,82. Peningkatan ini bermakna bahwa sektor-sektor usaha mampu menghasilkan produk yang memberikan nilai pendapatan tinggi setiap tahunnya. Pemerintah daerah provinsi NTB melalui kebijakan pembangunan strategis telah mampu mencapai hasil sesuai dengan target meskipun ada di antara lapangan usaha yang mencapai kurang dari 100 persen.

Pergerakan nilai tambah lapangan usaha setiap tahun juga merupakan ikhtiar yang dilakukan oleh pemerintah peovinsi Nusa Tenggara Barat. PDRB yang terlihat di atas akan dapat diketahui pula pergerakan pertumbuhan ekonomi provinsi Nusa Tenggara Barat setiap tahunnya. Hal ini terlihat dalam gambar berikut.

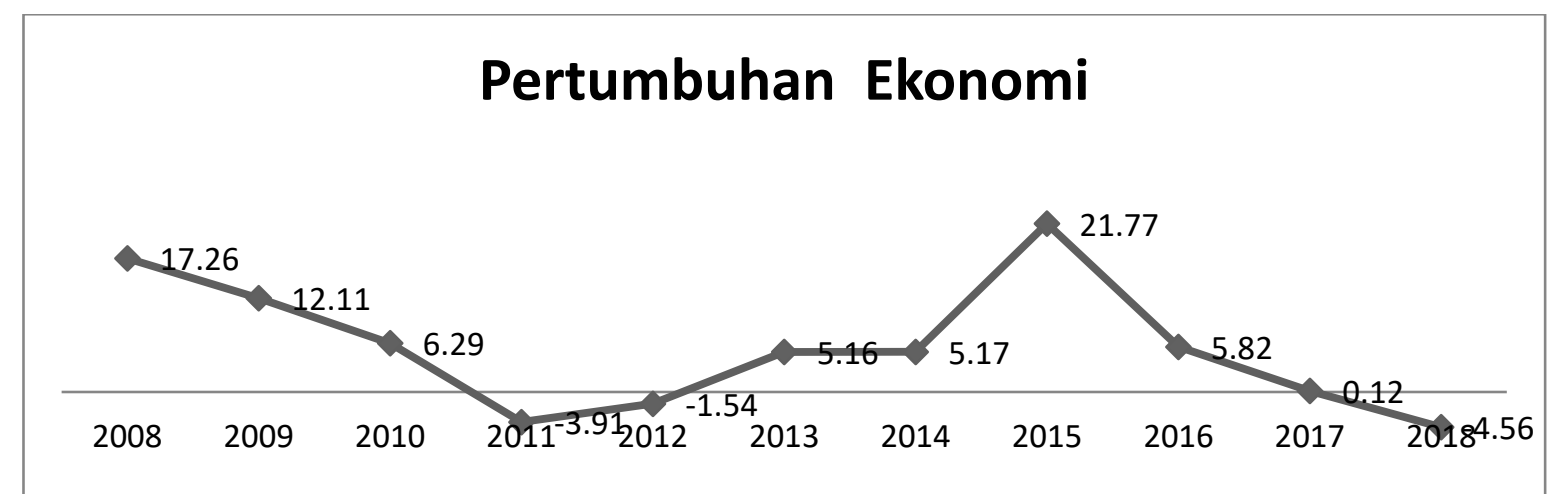

Gambar 1. Pertumbuhan Ekonomi Provinsi Nusa Tenggara Barat Berdasarkan Harga Konstan tahun 2008 - 2018 (Termasuk Sektor Tambang).

Pertumbuhan ekonomi termasuk tambang mengalami pergerakan yang tidak stabil. Pergerakan pertumbuhan ekonomi yang tidak stabil ini turut mempengaruhi perekonomian NTB. Dengan mengandalkan sektor tambang yang berada di Pulau Sumbawa yang dikelola oleh PT. Newmont Nusa Tenggara awalnya memberikan hasil yang menggembirakan. Produksi yang tinggi disertai dengan harga 
yang relatif baik, menyebabkan puncak penerimaan PDRB dengan sektor tambang terjadi pada tahun 2015. Berhentinya operasional PT Newmont membawa dampak terhadap perekonomian provinsi Nusa Tenggara Barat. Rasionalisasi karyawan dan tenaga kerja, ditandai dengan beralihnya tenaga kerja mencari pekerjaan pada sektor yang sama di daerah lain, pengurangan jam kerja sangat berdampak terhadap aktivitas ekonomi sector lainnya. Kondisi ini sangat berdampak pada sirkulasi barang maupun jasa serta distribusinya. Pertumbuhan ekonomi menurun tajam pada tahun 2018 hingga mencapai $-4,56$ persen.

Pertumbuhan ekonomi provimsi Nusa Tenggara Barat berdasarkan harga konstan 2010 dengan tidak memasukkan komponen pertambagan kondisinya berbeda dengan memasukkan unsur tambang. Pergerakan pertumbuhan ekonomi provinsi Nusa Tenggara Barat bergerak relatif stabil terkecuali pada tahun 2018 yang mengalami kontraksi atau penurunan. Hal ini menunjukkan bahwa nilai yang diperoleh dari non tambang semakin meningkat, seiring dengan semakin membaiknya jumlah produksi yang didukung oleh keadaan harga yang dapat dijangkau oleh masyarakat yang meminta barang tersebut. Kondisi pertumbuhan ekonomi tersebut dapat terlihat berikut.

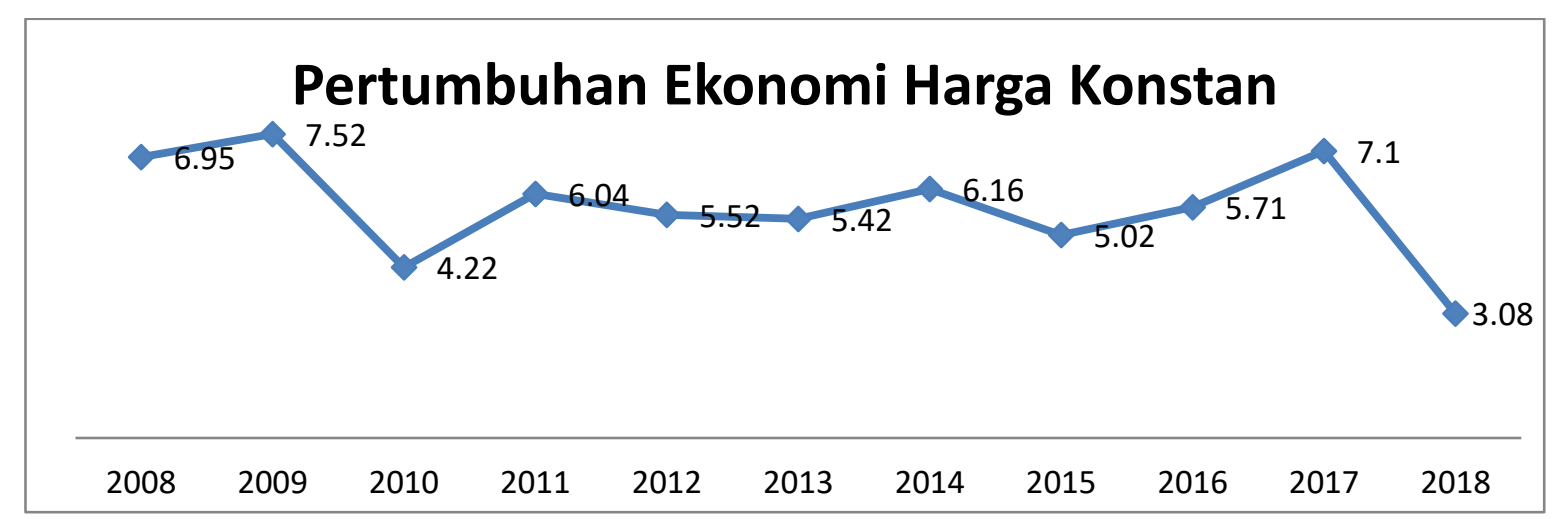

Gambar 2. Pertumbuhan Ekonomi Provinsi NTB Berdasarkan Harga Konstan, 2000 dan 2010 tahun 2008 - 2018 (Tidak Termasuk Sektor Tambang).

Pertumbuhan ekonomi berdasarkan harga konstan tahun 2010 tanpa tambang tertinggi pada tahun 2009 dan 2017 lebih dari 7 persen. Pertumbuhan ekonomi ini merupakan prestasi yang menggembirakan bagi provinsi Nusa Tenggara Barat di tengah kondisi perekonomian nasional yang berfluktuatif. Pergerakan pertumbuhan ekonomi hampir merata terjadi sepanjang tahun 2011 - 2016 antara 5 - 6 persen lebih. Pertumbuhan ekonomi tahun 2018 mengalami kontraksi yang sangat tajam dibanding tahun - tahun sebelumnya. Hal ini disebabkan adanya bencana gempa bumi yang melanda wilayah provinsi NTB pertengahan tahun 2018. Perisitiwa ini telah menyebabkan tidak berjalannya aktivitas masyarakat yang beradadi wilayah - wilayah yang dilanda musibah terutama aktivitas ekonomi. Pertumbuhan ekonomi yang berkualitas merupakan dambaan dari setiap negara maupun wilayah provinsi. Kabupaten/kota yang berada di dalam Negara tersebut. Pertumbuhan ekonomi berkualitas mencerminkan kemampuan pemerintah dalam mengelola sumber daya yang dimilikinya memberikan hasil yang meningkat dari tahun ke tahun. Imbas dari pertumbuhan ekonomi yang berkualitas berdampak pada kualitas kehidupan masyarakat yang diukur dari jumlah penduduk miskin dan tingkat penangguran. Hasil analisis dan pembahasan terhadap besaran dan pergerakan pertumbuhan ekonomi menunjukkan hasil 


\section{Elastisitas - Jurnal Ekonomi Pembangunan \\ Vol. 2 No. 2, September 2020}

yang selalu berfluktuatif dan cendrung naik dan turun. Pada priode pembangunan 2008 - 2013 pertumbuhan ekonomi provinsi Nusa Tenggara Barat berdasarkan harga konstan 2010 secara rata-rata mencapai angka sebesar 5,95\%. Sementara rata rata pertumbuhan ekonomi dari tahun 2014 - 2018 sebesar 5,41 \% sedikit menurun dari priode sebelumnya. Rata-rata pertumbuhan ekonomi provinsi Nusa Tenggara Barat tahun 2009 - 2018 baru mencapai sebesar, 5,70 persen. Melihat kondisi demikian, maka kinerja pemerintah provisi Nusa Tenggara Barat untuk mencapai sasaran pertumbuhan ekonomi lebih besar dari 6 persen tidak dapat tercapai. Dilihat dari besarnya capaian pertumbuhan ekonomi ini maka dapat dikatakan bahwa pertumbuhan ekonomi privinsi Nusa Tenggara Barat tergolong berkualitas rendah, karena masih berada di bawah 7 persen (Stamboel, 2012). Kualitas pertumbuhan ekonomi tidak hanya dilihat dari satu aspek, namun semua aspek pembangunan memiliki kertaitan (linkage) antara satu dengan yang lainnya. Sebagaimana yang telah diuraikan sebelumnya, terdapat beberapa indikator yang menjadi ciri dari pertumbuhan ekonomi yang berkualitas.

\section{A. Pertumbuhan Ekonomi dan} Kemiskinan Penduduk

Kemiskinan merupakan permasalahan mendasar yang kerap dihadapi dalam proses pembangunan suatu Negara maupun daerah termasuk di provinsi Nusa Tenggara Barat. Kemiskinan menunjukkan kualitas sumber daya sebagai modal pembangunan masih berada dalam kondisi yang belum menguntungkan dilihat dari aspek material. Berbagai kebijakan dari tahun ke tahun telah digelontorkan oleh pemerintah provinsi hingga ke kabupaten/kota untuk mengurangi penduduk dari jeratan kemiskinan. Berbagai program yang telah dilakukan mampu menurunkan jumlah penduduk miskin terlihat berikut.

Tabel 3. Jumlah dan Persentase Penduduk Miskin di Provinsi Nusa Tenggara Barat Tahun $2008-2018$.

\begin{tabular}{|c|c|c|c|}
\hline No & Tahun & Jumlah (orang) & Jumlah Penurunan (org) \\
\hline 1 & 2008 & 1.080 .613 & -29.665 \\
\hline 2 & 2009 & 1.050 .948 & -41.586 \\
\hline 3 & 2010 & 1.009 .362 & -114.586 \\
\hline 4 & 2011 & 894.776 & -66.446 \\
\hline 5 & $2012^{*}$ & 828.330 & -25.882 \\
\hline 6 & 2013 & 802.448 & 14.173 \\
\hline 7 & 2014 & 816.621 & -14.329 \\
\hline 8 & 2015 & 802.292 & -15.711 \\
\hline 9 & 2016 & 786.581 & -38.459 \\
\hline 10 & 2017 & 748.122 & -12.502 \\
\hline 11 & 2018 & 735.620 & \\
\hline & Rata-rata & 31.363. & \\
\hline
\end{tabular}

Sumber : RPJMD NTB 2013 - 2018; 2018 -2023; BPS NTB; 2019, diolah.

*) Kondisi Bulan September sejak tahun 2012

Tabel di atas memberikan gambaran bahwa selama 10 tahun terakhir pemerintah provinsi Nusa Tenggara Barat telah mampu menurunkan jumlah penduduk miskin meskipun pada tahun 2014 terjadi peningkatan jumlah penduduk 


\section{Elastisitas - Jurnal Ekonomi Pembangunan \\ Vol. 2 No. 2, September 2020}

miskin dari tahun - tahun sebelumnya. Meskipun penurunan penduduk miskin belum mampu mencapai target yang telah ditetapkan, namun hasil yang diperoleh ini cukup menggembirakan. Penurunan jumlah penduduk miskin dapat dihubungkan dengan pertumbuhan ekonomi. Secara teoritis terdapat hubungan yang kuat antara pertumbuhan ekonomi dan penurunan penduduk miskin. Sisi lain, pengaruh pertumbuhan ekonomi terhadap kemiskinan adalah negatif, artinya semakin tinggi pertumbuhan ekonomi akan diikuti oleh terjadinya penurunan jumlah maupun persentase penduduk miskin.

Pertumbuhan ekonomi privovinsi Nusa Tenggara Barat yang cendrung berfluktuatif naik dan turun tidak diikuti oleh berfluktuatifnya persentase penduduk miskin. Tekad pemerintah untuk meningkatkan kualitas sumber daya manusia melalui penurunan penduduk miskin terus dilakukan setiap tahunnya. Alokasi anggaran untuk penurunan penduduk miskin semakin ditingkatkan, sehingga dengan berbagai kebijakan yang sudah dan akan ditempuh, ditargetkan pada tahun 2013, persentase penduduk miskin mencapai 14,00 persen. Demikian halnya, dengan pertumbuhan ekonomi, ditargetkan akan mencapai angka 6,5-7,0 persen pada tahun 2013 (Bappeda, 2012).

Ikhtiar membangun daerah salah satunya meningkatkan pertumbuhan ekonomi agar terjadi penurunan penduduk miskin telah diikhtiarkan dan telah memberikan hasil yang menggembirakan. Pertumbuhan ekonomi bergerak naik dan turun sementara kemiskinan cenderung bergerak turun. Hal ini menandakan bahwa antara pertumbuhan ekonomi dan penurunan penduduk miskin tidak selalu berhubungan kuat dan berlawanan arah sebagaimana terlihat dalam gambar berikut.

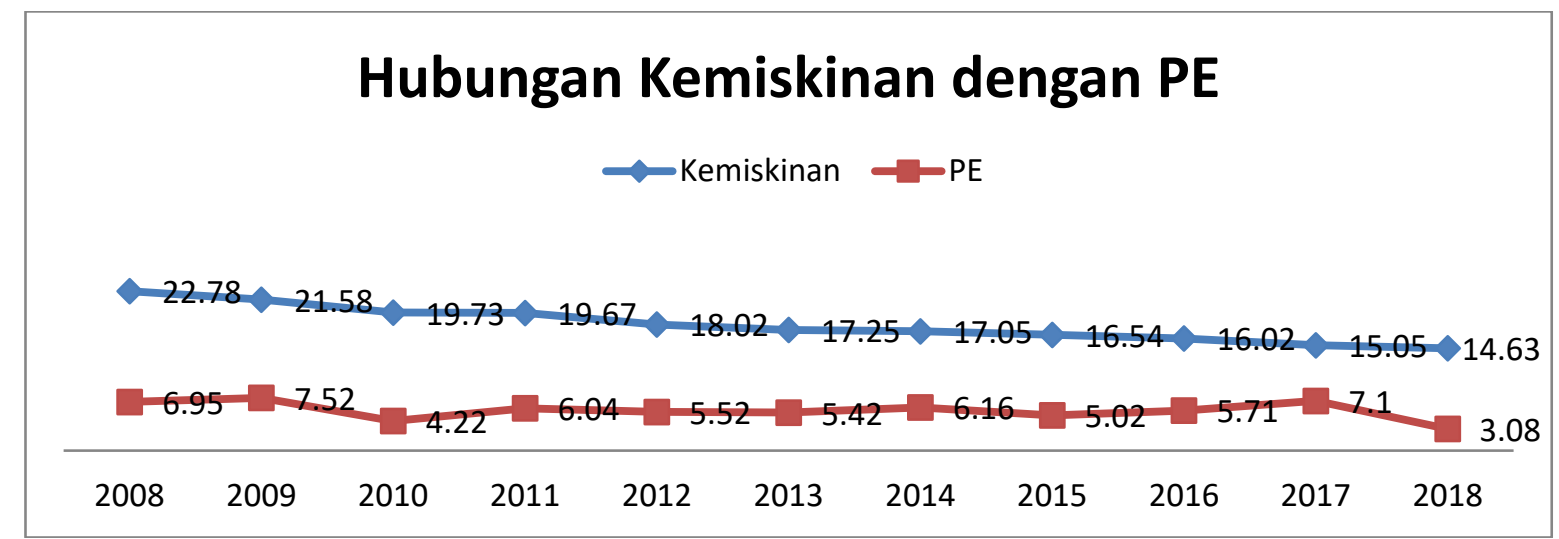

Gambar 3. Hubungan Antara Pertumbuhan Ekonomi dan Kemiskinan di Nusa Tenggara Barat Tahun 2008 - 2018 (\%).

Terlihat di dalam gambar, bahwa pada tahun 2008 - 2013 ketika pertumbuhan ekonomi bergerak naik dan turun, persentase penduduk miskin justru terus menurun. Pada tahun 2010 pertumbuhan ekonomi mengalami penurunan, tetapi persentase penduduk miskin mengalami penurunan sekitar 1,85 persen dan merupakan penurunan yang terbesar selama priode analisis. Demikian halnya ketika pertumbuhan ekonomi mengalami peningkatan tidak serta merta diikuti oleh penurunan kemiskinan baik dari jumlah maupun persentase. Target yang dicanangkan baik untuk penduduk miskin maupun pertumbuhan ekonomi priode 2008 - 2013 tidak tercapai.

Kinerja pembangunan ini menandakan bahwa dengan capaian pertumbuhan ekonomi pada tahun 2013 hanya sebesar 5,42 persen berarti belum mampu mencapai target yang telah ditetapkan. rata - rata pertumbuhan ekonomi sebesar 5,95 persen kualitas 
pertumbuhan ekonomi provinsi Nusa Tenggara Barat masih rendah sehingga baru mampu merealisasikan persentase penduduk miskin sebesar 18,02 persen masih jauh dari target yang telah ditetapkan sebesar 14,00 persen. Pada priode ini, penurunan persentase penduduk miskin rata- rata mencapai 1,11 persen juga maih lebih kecil dari target yang ditetapkan sebesar 2 persen.

Kinerja pemerintah untuk membawa pertumbuhan ekonomi yang relatif baik dan berkualitas pada tahun 2014 menunjukkan keadaan yang sangat menggembirakan dengan mampu mencapai angka di atas 6 persen yaitu 6,16 persen bahkan melebihi target yang ditetapkan sebesar 5,60 - 5,75 persen. Namun pada tahun 2015 -2016 pertumbuhan ekonomi mengalami penurunan dan lebih rendah dari target yang ditetapkan. Banyak faktor dan kendala yang dihadapi oleh pemerintah provinsi Nusa Tenggara Barat pada tahun tahun ini baik bersifat internal maupun eksternal. Pada tahun 2017 pertumbuhan ekonomi yang dicapai cukup tinggi dan berada pada kualitas tinggi mencapai 7,1 persen jauh melewati target yang ditetapkan sebesar 6,0-6,25 persen.

Uraian sebelumnya menjelaskan pertumbuhan ekonomi provinsi Nusa Tenggara Barat tahun 2018 mengalami kontraksi yang cukup tajam akibat berbagai musibah dan bencana yang melanda daerah ini, terutama gempa bumi sejak pertengahan tahun 2018. Berbagai bencana dan musibah tersebut sangat berdampak pada aktivitas ekonomi masyarakat. Capaian pertumbuhan ekonomi hanya 3,08 persen sangat jauh dari target yang ditetapkan sebesar 6,25 6,50 persen. Secara rata - rata pertumbuhan ekonomi NTB pada tahun 2014 - 2018 mencapai 5,14 persen, dan berada dalam kualitas rendah. Rendahnya kualitas ini setidaknya berdampak pada penurunan persentase angka kemiskinan.

Hubungan pertumbuhan ekonomi berkualitas dengan penurunan persentase kemiskinan pada priode 2008 - 2018 secara umum terjadi hubungan yang linier, artinya jika terjadi penurunan pertumbuhan ekonomi tidak serta merta diikuti dengan naiknya persentase penduduk miskin atau sebaliknya. Bahkan ketika pertumbuhan ekonomi bergerak naik persentase penduduk miskin bahkan bergerak turun. Berdasarkan gambaran ini, maka pertumbuhan ekonomi yang baik atau berkualitas belum mampu sepenuhnya diikuti oleh penurunan persentase penduduk miskin yang lebih besar. Dengan demikian, kondisi ini akan menjadi pertimbangan bagi pemerintah masa-masa selanjutnya, untuk memperhatikan aspekaspek lain yang dapat mempercepat penurunan kemiskinan di samping pertumbuhan ekonomi yang berkualitas.

Menurut Maipita (2014), kebijakan yang dapat ditempun berkenaan dengan penurunan penduduk miskin adalah kebijaksanaa fiskal. Wujud dari kebijakan ini dapat dilihat dari perkembangan pendapatan dan pengeluaran Anggaran Pendapatan dan Belanja Negara (APBN) yang merupakan isntrumen penting kebijakan pemerintah. Instrumen ini tidak hanya sekedar dipahami sebagai suatu dokumen keuangan semata, melainkan juga harus dipahami sebagai dokumen politik. Dokumen APBN juga merefleksikan komitmen politik dan prioritas kebijakan sosial ekonomi pemerintah. Badruddin (2012) mengatakan bahwa menurunkan penduduk dari kemiskinanh harus dapat dilihat dari berbagai aspek seperti pendidikan, kesehatan, ekonomi, kultur dan struktural. Penanggulangan kemiskinan tidak hanya dilihat dari aspek materi tetapi meliputi aspek spritual seperti keadilan, dilaksanakan secara berkelanjutan bukan dengan cara permanen dan temporer.

\section{B. Pertumbuhan Ekonomi dan Tingkat Pengangguran}

Pertumbuhan ekonomi yang berkualitas tidak hanya diharapkan akan mampu menurunkan penduduk dari kemiskinan yang disertai oleh daya beli yang tinggi, namun dapat dilihat pula dari 


\section{Elastisitas - Jurnal Ekonomi Pembangunan \\ Vol. 2 No. 2, September 2020}

aspek lain yaitu tingkat pengangguranPertumbuhan ekonomi berkualitas yang dicirikan di antaranya mampu menyediakan kesempatan kerja yang cukup besar yang dipicu oleh pertumbuhan investasi yang bersifat padat karya bukan bersifat padat modal (Arsyad, 2000). Pertumbuhan ekonomi yang berkualitas setidaknya mampu mengurangi penduduk dari pengangguran karena tersedianya kesempatan kerja.

Jumlah penduduk yang menganggur di provinsi Nusa Tenggara Barat mengalami dinamika yang naik dan turun setiap tahun.
Hal ini bermakna bahwa pada saat yang bersamaan telah tercipta lapangan lapangan kerja baru dan juga terdapat penduduk yang keluar dan tidak memiliki kesempatan kerja yang menyebabkan mereka menganggur lagi. Berfluktuasinya angka pengangguran ini menunjukkan bahwa di provinsi Nusa Tenggara Barat masih belum dapat menjamin sepenuhnya terciptanya kesempatan kerja bagi penduduknya . Demikian halnya sektor sektor swasta sebagai mitra pemerintah menunjukkan keadaan yang sama. Jumlah penganggutran di NTB terlihat berikut.

Tabel 4. Jumlah Penduduk Yang Menganggur di Provinsi Nusa Tenggara Barat Tahun 2008 -2018 .

\begin{tabular}{|c|c|c|c|c|c|}
\hline No & Tahun & Jumlah (orang) & Penurunan & Pertumbuhan (\%) & TPT (\%) \\
\hline 1 & 2008 & 124.300 & - & - & 6,48 \\
\hline 2 & 2009 & 131.258 & 6.958 & 5,60 & 6,25 \\
\hline 3 & 2010 & 119.143 & -12.115 & $-9,23$ & 5,29 \\
\hline 4 & 2011 & 110.542 & -8.601 & $-7,22$ & 5,33 \\
\hline 5 & 2012 & 109.948 & -594 & $-0,54$ & 5,47 \\
\hline 6 & 2013 & 112.708 & 2.760 & 2,51 & 5,25 \\
\hline 7 & 2014 & 127.710 & 15.002 & 13,31 & 5,73 \\
\hline 8 & 2015 & 128.376 & 666 & 0,52 & 5,69 \\
\hline 9 & 2016 & 97.621 & -30.755 & $-23,96$ & 3,94 \\
\hline 10 & 2017 & 79.449 & -18.172 & $-18,61$ & 3,32 \\
\hline 11 & 2018 & 83.260 & 3.811 & 4,80 & 3,72 \\
\hline
\end{tabular}

Sumber :Data Sekunder, diolah.

Terlihat bahwa tahun $2010-2012$ terjadi penurunan jumlah pengangguran. Penurunan jumlah penduduk yang menganggur dari tahun 2008 - 2018 mencapai 41.040 orang atau rata- rata mencapai 3.731 orang setiap tahun. Dilihat dari jumlah penurunan ini belum memberikan hasil yang signifikan sehingga terus menjadi permasalahan yang akan dihadapi oleh pemerintah provinsi Nusa Tenggara Barat pada tahun - tahun mendatang. Pemerintah harus terus membuatkan kebijakan - kebijakan strategis untuk mencuptakan kesempatan kerja baru. Pemerintah dengan berbagai kebijakan terhadap pelaksanaan investasi yang telah dilakukan akan berdampak pada hadirnya investor di daerah ini. Investasi merupakan salah satu faktor yang menciptakan lapangan kerja bagi para penganggur.

Pertumbuhan jumlah penduduk yang menganggur setiap tahunnya juga berbeda-beda dengan pertumbuhan tertinggi terjadi pada tahun 2014 sebesar 13,31 persen, sedangkan pertumbuhan penuruna pengangguran terjadi pada tahun 2016 sebesar negatif 23,96 persen. Secara rata - rata pertumbuhan jumlah penggangguran sebesar negatif 3,28 
persen. Terjadinya penurunan dan kenaikan jumlah dan pertumbuhan pengangguran tidak terlepas dengan berbagai kondisi baik dari sisi ekonomi, sosial dan politik. Khususnya pada aktivitas politik, bila pada tahun tersebut terjadi kontestasi pemilihan Kepala Daerah maupun Anggota Legislatif, menyebabkan terbukanya kesempatan kerja musiman, mengikuti permintaan yang berkenaan dengan atribut kegiatan politik.

Tingkat Pengangguran Terbuka (TPT) ini juga dapat dilihat hubungannya dengan kualitas pertumbuhan ekonomi pada priode yang sama. Menurut Arthur Okun (1962) yang dikenal dengan huku Okun mengatakan bahwa adanya hubungan yang negatif linier antara pengangguran dan pertumbuhan ekonomi. Setiap kenaikan tingkat pengangguran $1 \%$ akan menyebabkan menurunnya pertumbuhan ekonomi sebesar 2 persen atau lebih. Sebaliknya, $1 \%$ kenaikan pertumbuhan ekonomi menyebabkan penurunan tingkat pengangguran sebesar 1 $\%$ atau kurang (Kuncoro, 2013). Bekerjanya hukum Okun ini dapat diaplikasikan untuk melihat hubungan antara pertumbuhan ekonomi dan tingkat pengangguran terbuka yang terjadi di provinsi Nusa Tenggara Barat. Secara grafis hubungan tersebut seperti terlihat dalam gambar berikut.

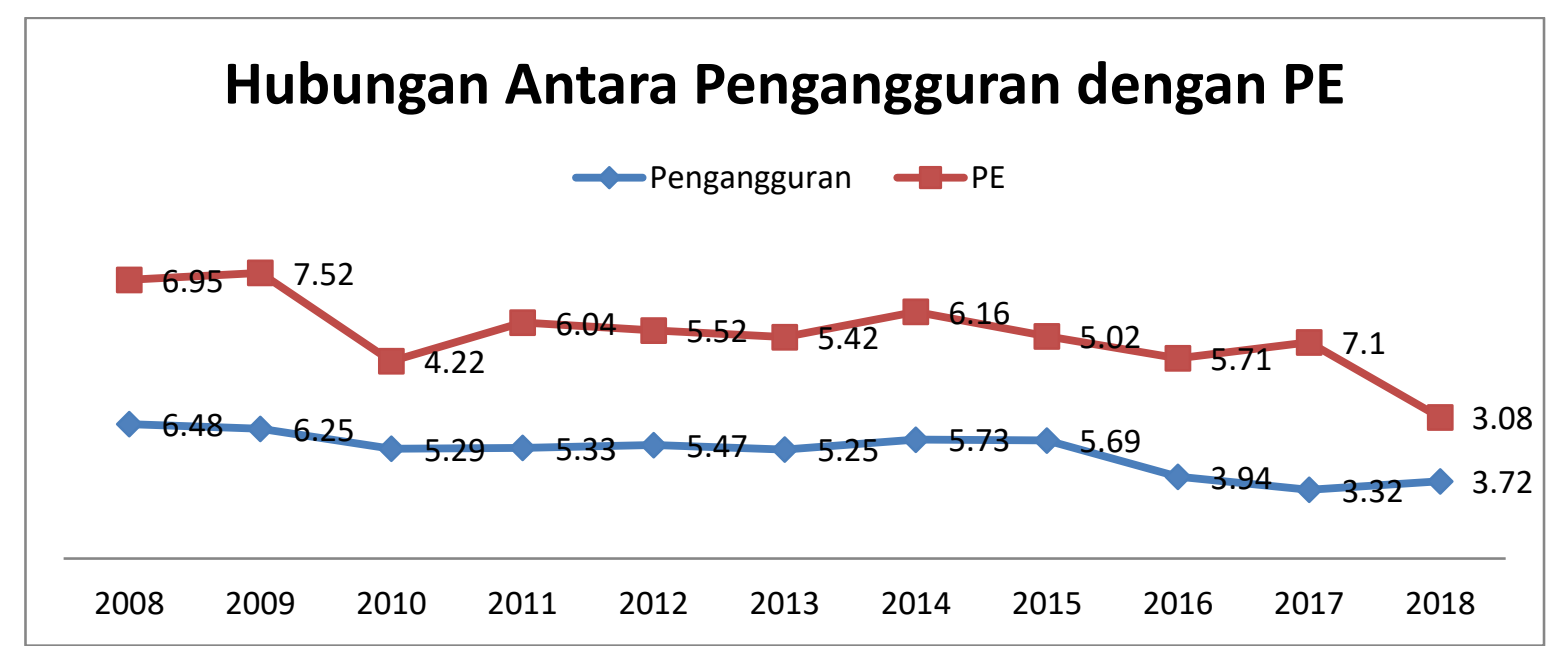

Gambar 4. Hubungan Antara Pertumbuhan Ekonomi dan Tingkat Pengangguran Terbuka di Nusa Tenggara Barat Tahun $2008-2018$ (\%).

Pergerakan pertumbuhan ekonomi dengan Tingkat Pengangguran Terbuka (TPT) adalah searah dan tidak searah. Artinya jika pertumbuhan ekonomi mengalami peningkatan maka pengangguran akan mengalami peningkatan, demikian pula yang terjadi sebaliknya. Hubungan tidak searah (terbalik) hanya terjadi pada tahun 2016 2017 ketika pertumbuhan ekonomi naik, TPT mengalami penurunan yang cukup tinggi, dan pada tahun 2018 ketika pertumbuhan ekonomi mengalami kontraksi maka pengangguran ikut terpengaruh yaitu mengalami peningkatan dari tahun sebelumnya. Secara rata-rata, persentase jumlah pengangguran terbuka selama priode analisis mencapai 5,13\% hampir sama dengan rata - rata pertumbuhan ekonomi. Artinya ketika pertumbuhan ekonomi berada pada kondisi yang berkualitas rendah, diikuti pula oleh terjadinya jumlah TPT yang masih relatif tinggi. Dengan demikian, pertumbuhan ekonomi nusa Tenggara Barat belum mampu membawa TPT pada level yang lebih rendah dari rata-rata pertumbuhan ekonomi.

Capaian pemerintah menurunkan Tingkat Pengangguran Terbuka (TPT) meskipun mengalami fluktuasi dari tahun ke tahun namun telah mampu melebihi 
target yang ditetapkan. Pemerintah telah menetapkan target bahwa pata tahun 2018 TPT akan berada pada angka 4,56 persen, sementara TPT pada tahun tersebut sebesar 3,72 persen. Meskipun daerah ini pada tahun 2018 mendapatkan bencana gempa bumi, peningkatan jumlah TPK hanya sebesar 0,40 persen dibandingkan dengan perubahan pertumbuhan ekonomi sebesar negatif 4,02 persen. Dengan demikian hukum Okun belum sepenuhnya berlaku di provinsi Nusa Tenggara Barat. Hal ini dapat dilihat bahwa bila terjadi pertumbuhan ekonomi yang naik sebesar 1 persen tidak diikuti oleh menurunnya pengangguran sebesar $1 \%$. Bahkan pertumbuhan ekonomi yang turun sebesar 4 persen, TPT hanya meningkat 0,40 persen.

\section{Pertumbuhan Ekonomi Berkualitas dan Maqashid Syariah}

Pemenuhan kesejahteraan melalui pertumbuhan ekonomi yang berkualitas telah dirancang oleh ekonomi Islam melalui maqashid syariah (tujuan syariah). Tujuan syari'ah yang ingin dicapai adalah upaya manusia untuk memenuhi kebutuhan dasarnya agar dapat bertahan hidup, memanfaatkan seluruh potensi sumber daya yang tersedia dengan berusaha untuk tidak melakukan kerusakan, serta mengedepankan nilai-nilai etika islami yang bermuara terciptanya keadilan dalam distribusi sumber daya. Jika hal ini terlah mampu dilaksanakan secara istiqmah, secara otomatis kemaslahatan dan kesejahteraann kehidupan di dunia maupun di akhirat yang dituju akan dapat diraih. Pertumbuhan ekonomi yang berkualitas dapat dikaitkan dengan salah satu dari kategori hukum Daruriyat yaitu kebutuhan yang mendesak dan darurat, sehingga wajib untuk diwujudkan pemenuhannya agar manusia terselamatkan dalam proses kehidupannya. Lima kebutuhan pokok yang harus dipenuhi dan dipelihara adalah kebutuhan terhadap agama, kebutuhan terhadap jiwa, kebutuhan terhadap akal, kebutuhan terhadap keturunan dan kebutuhan terhadap harta..

\section{Kualitas Pertumbuhan Ekonomi dan Kebutuhan Menjaga Agama}

Manusia beriman adalah manusia yang selalu menjalani perintah agama dalam aktivitas kehidupannya sehari-hari. Manusia wajib membutuhkan agama, wajib pula memelihara dan menjaganya. Salah satu cara menjaga kemurnian dan kesucian agama adalah melalukan segala perintah agama untuk kebaikan kehidupan dan berusaha semaksimal mungkin untuk tidak melanggar karena akan membawa bencana dan malapetaka dalam perjalanan hidup manusia di dunia terlebih di akhirat. Menghadirkan agama di dalam membangun daerah dan perekonomian merupakan suatu keharusan dan kewajiban. Nilai - nilai yang terkandung di dalam ajaran agama merupakan landasan primer bagi suatu sItem perekonomian. Sistem ekonomi Islam Mewujudkan pertumbuhan ekonomi berkualitas harus berlandaskan ajaran Ilahiah yang terurai dalam ajaran agama.

Pertumbuhan ekonomi yang berkualitas dapat dicapai manakala pelaksana pembangunan daerah dijalankan oleh Sumber Daya Manusia yang berkualitas pula. Manusia yang dipercaya untuk menjalankan roda pemerintahan, penentu dan pembuat keputusan serta sebagai pelaku ekonomi harus menjaga amanah dan dijalankan dengan jujur dan adil. Sebagai pejabat negara yang mendapat mandat dari rakyat, tidak menyalahgunakan kekuasaannya dengan melanggar sumpah dan janji yang telah disanggupinya. Menjalani jabatan yang diembannya dengan jujur, amanah, adil berarti telah menjaga sekaligus memelihara ajaran agama yang dianutnya. Dia butuh nilai - nilai ajaran agama dalam mengimplementasikan tugas yang diembannya. Dia berusaha untuk berada pada jalan yang lurus, tidak melakukan kecurangan, manipulasi, kebohongan dan melakukan korupsi.

Korupsi, Kolusi, Nepotisme dan suap menyuap merupakan pintu hancurnya pembangunan ekonomi suatu negara 
maupun daerah. Ia adalah laksana gula yang tak pernah habis rasa manisnya. Kasus korupsi dan sejenisnya juga terjadi di Nusa Tenggara Barat baik dilakukan oleh aparat negara maupun pihak - pihak swastra. Prinsip beriman yang dicanangkan oleh pemerintah provinsi Nusa Tenggara Barat telah memberikan hasil yang bermanfaat bagi masyarakat yang dibuktikan dengan bertambahnya fasilitas ibadah maupun lembaga - lembaga keagamaan. Namun sisi lain, jumlah tindakan korupsi juga masih menyertai perjalanan proses pembangunan daerah ini. Kasus tindak pidana korupsi yang ditangani oleh Pengadilan TIPIKOR menunjukkan keadaan yang sangat memprihatinkan seperti terlihat berikut.

Tabel. 5. Jumlah Kasus Korupsi Yang Sudah Dilaksanakan Tuntutan di Pengadilan TIPIKOR

\begin{tabular}{|c|c|c|c|}
\multicolumn{1}{|c}{ NTB 2014 - 2108. } \\
\hline No & Tahun & Korupsi /Tuntutan & $\begin{array}{c}\text { Uang Negara Yang Diselamatkan } \\
(\mathrm{Rp})\end{array}$ \\
\hline 1 & 2014 & 52 & $385.740 .588,18$ \\
\hline 2 & 2015 & 21 & $7.934 .711 .741,91$ \\
\hline 3 & 2016 & 34 & $9.560 .878 .612 ., 42$ \\
\hline 4 & 2017 & 46 & $2.060 .897 .752,07$ \\
\hline 5 & 2018 & 31 & $3.442 .714 .624,08$ \\
\hline & Jumlah & 184 & $13.824 .064 .706,24$ \\
\hline & Rata2 & 36,8 & $2.764 .812 .941,25$ \\
\hline
\end{tabular}

Sumber. NTB Dalam Angka

Tindak pidana korupsi yang dilakukan oleh para koruptor merupakan penghambat untuk terwujudnya tujuan pembangunan. Jumlah tindakan korupsi bervariatif setiap tahun yang menyebabkan kerugian negara yang sangat besar. Dengan terjadinya tuntutan terhadap para koruptor, maka uang negara juga yang sejatinya untuk pembangunan kepentingan rakyat dapat diselamatkan. Jumlah kasus korupsi yang rata-rata mencapai 37 kasus setiap tahun menunjukkan bahwa manusia NTB masih belum mampu memelihara dan menjaga agamanya. Islam secara jelas memberikan ancaman bagi pelaksana dan pelaku korupsi dan sejenisnya. Islam mengatakan bahwa orang - orang yang melakukan konsumsi dengan menggunakan uang hasil korupsi sesungguhnya dia telah menimbun daging di dalam diri dan keluarganya. Firman Allah dalam surat Al-Baqarah 188 yang artinya "Dan janganlah kamu sebahagian kamu memakan harta sebahagian yang lain di antara kamu dengan jalan yang bathil dan (janganlah) kamu membawa (urusan) harta itu kepada hakim, supaya kamu dapat memakan sebahagian daripada harta benda orang lain itu dengan (jalan berbuat) dosa, padahal kamu mengetahui". Ayat ini memerintahkan manusia untuk mengkonsumsi sesuatu yang halal tanpa menimbulkan kerugian bagi pihak lain. Pejabat mengkonsumsi sesuai dengan pendapatan yang diperolehnya, demikian juga dengan manusia lain yang melakukan aktivitas- aktivitas di dalam maupun di luar pemerintahan termasuk dalam aktivitas ekonomi.

Kemudian Rasulullah SAW bersabda yang artinya "Barang siapa diserahi suatu jabatan sedang ia tidak punya rumah, maka berikanlah rumah untuknya, bila tidak punya isteri maka kawinkanlah dia, bila tidak punya pembantu maka berilah dia pembantu dan jika ia tidak punya kendaraan maka sediakanlah baginya. Barang siapa mengambil sesuatu selain itu, maka dia adalah koruptor" (HR. Imam Ahmad). Pejabat yang melaksanakan amanah dari rakyat, hendaknya diberikan 
berbagai fasilitas yang mendukung jabatannya, untuk menghindari dari perbuatan curang berupa korupsi dan sejenisnya. Islam telah memberikan petunjuk secara jelas kepada manusia untuk menghindari melalukan suatu tindakan memperkaya diri sendiri dengan mengabaikan bahkan tidak menghiraukan kepentingan orang lain.

Agama merupakan kebutuhan asasi manusia yang wajib dijaga dan dipelihara, Menghadirkan agama dalam setiap aktivitas untuk menata dan membangun negara atau daerah adalah suatu keharusan. Agama Islam melalui hukum - hukum Allah dan sunah Rasulullah telah memberikan gambaran hancurnya suatu kaum atau bangsa karena jauh dari ajaran agama. Berbagai peristiwa, bencana dan malapetaka yang menimpa suatu negara atau daerah karena melanggar dengan sengaja nilai- nilai ajaran agama. Agama Islam merupakan jalan kedamaian, jalan keselamatan, jalan lurus yang menghantarkan manusia untuk mewujudkan impiannya. Agama adalah cahaya terang benderang yang menyinari jiwa dan sanubari manusia dari jalan kegelapan dan kesengsaraan.

\section{Kualitas Pertumbuhan Ekonomi dan Kebutuhan/Menjaga Jiwa}

Jiwa adalah unsur kehidupan yang melekat pada semua makhluk termasuk manusia. Jiwa merupakan suatu kebutuhan pokok bagi manusia, sehingga perlu dijaga dan dipelihara kesuciannya. Manusia yang beriman harus mampu membebaskan diri dari berbagai penyakit jiwa yang selalu berjalan bersama dengan nafsu yang mengarah pada perbuatan negatif. Pertumbuhan ekonomi yang berkualitas tidak mungkin akan dapat digapai manakala pelakunya dalam melakukan berbagai aktivitas tidak disertai dengan ketentraman jiwa. Pertumbuhan ekonomi yang berkulitas dapat diraih manakala setiap manusia mengisi hidupnya dengan melakukan aktivitas bekerja dan berkarya. Dari bekerja akan diperoleh produk barang dan jasa yang memberikan pendapatan bagi diri, kelurga, orang lain dan negara. Pertumbuhan ekonomi berkualitas dicapai bila tersedia kesempatan kerja, terdapat manusia yang mau mencurahkan tenaga dan pikirannya untuk bekerja.

Manusia yang menjaga jiwanya adalah manusia yang memanfaatkan potensi fundamental yang dimilikinya adalah akal sebagai alat untuk berpikir. Potensi akal yang dimiliki selalu memanfaatkan waktu yang ada untuk bekerja dan tidak dibiarkan berlalu tanpa aktivitas atau menganggur. Menganggur adalah salah satu faktor yang menghambat berkembangnya kualitas kehidupan manusia. Menganggur dapat disebabkan oleh berbagai hal di antaranya karena adanya sifat malas dan takabur. Sifat malas dan takabur merupakan penyakit jiwa yang dapat membawa dampak sangat buruk bagi manusia itu sendiri maupun orang lain.

Jumlah penduduk yang menganggur sebagaimana ditampilkan dalam tabel di atas, dapat disebabkan oleh adanya penduduk yang memiliki sifat malas dan takabur ini. Sifat malas berkaitan dengan penyakit jiwa yang tidak mau mengembangkan dirinya karena dipengaruhi oleh nafsu yang tidak baik. Sedangkan takabur adalah sikap seseorang terhadap pekerjaan yang ada tidak cocok untuk dirinya dan menganggap dirinya terhina bekerja pada bidang tertentu. Ia memandang dirinya serba tinggi dan pekerjaan yang digelutinya harus sesuai dengan keadaannya pada saat itu. Sikap demikian merupakan sikap dari seseorang yang tidak mampu menjaga jiwanya, dan justru akan menjeruuskan dirinya ke lembah kehinaan dan kenistaan.

Seseorang yang terjangkit penyakit jiwa malas dan takabur membawa dampak dalam kehidupan sosialnya. Masyarakt merasah terganggu dengan kehadirannya, dan bahkan dianggap sebagai sampah masyarakat. Rasulullan SAW bersabda "Aku berlindung kepada-Mu (Allah) dari datangnya takabur yang dengan tibatiba”. Lebih lanjut Rasulullah SAW 
bersabda "Tidak dapat masuk surga seseorang yang di dalam hatinya terdapat seberat dari sifat ketakaburan. Berkaitan dengan sifat malas, Rasulullah SAW bersabda "Sedekah tidak halal buat orang yang kaya dan orang yang masih mempunyai kekuatan dengan sempurna (HR. Tirmizi). Dengan sifat malas ia enggan bekerja dan lebih senang memintaminta pada orang lain, padahal ia tidak begitu membutuhkannya, tidak disadarinya sikap tersebut dapat menurunkan harga dirinya. Malas merupakan penyakit jiwa yang akan menular tubuh manusia dengan berbagai jenis penyakit lainnya. Malas tidak melakukan aktivitas bekerja menyebabkan organ - organ tubuh yang lain kaku karena tidak ada gerakan. Malas merupakan penyakit jiwa yang sulit disembuhkan karena sudah mendarah daging di dalam tubuh manusia. Oleh karenanya, malas adalah penghambat majunya peradaban manusia. Aktivitas ekonomi sebagai aktivitas yang selalu menyertai perjalanan hidup manusia akan terhambat karena adanya sifat malas.

\section{Kualitas Pertumbuhan Ekonomi dan Kebutuhan/Menjaga Akal (Ilmu)}

Akal merupakan salah unsur kehidupan yang dimiliki oleh makhluk yang bernama manusia. Akallah yang akan menghantartkan manusia menjdi makhluk yang terhormat atau yang terhina. Akal merupakan sumber hikmah (pengetahuan), sinar hidayah cahaya mata hati dan media kebahagiaan manusia di dunia dan di akhirat. Setiap kali manusia mengoperasikan pikiran dan akalnya, menggunakan mata hati dan perhatiannnya, dia akan memperoleh rasa aman, merasakan kedamaian dan ketenangan, dan masyarakat tempat dia hiduppun akan didominasi oleh suasana yang penuh dengan rasa sayang, cinta, dan ketenangan. Manusiapun akan merasa aman atas harta, jiwa, kehormatan dan kemerdekaan mereka (Jauhar, 2009).

Pertumbuhan ekonomi yang berkualitas mampu mengangkat harkat dan martabat manusia menjadi berklualitas yang ditandai dengan semakin membaiknya kualitas ilmu dan pengetatahuan (pendidikan). Orang yang berpendidikan adalah orang yang mampu memfaatkan dan menjaga akalnya dengan baik. Dengan akal dan ilmu pengetahuan yang dimiliki, manusia mampu memikirkan hal - hal yang bermanfaat, memutuskan segala sesuati secara rasional, tidak emosional dan jauh dari bisikan nafsu yang mengarah pada tindakan irrasional. Orang yang memiliki dan mampu menjaga akalnya, tidak akan melakukan dan menjadikan segala sesuatu yang rasional menjadi irrasional atau sebaliknya.

Akal rasional merupakan kebutuhan pokok bagi manusia, karena akan membawa manusia amenjadi orang yang memiliki derajat yang tinggi. Dengan akal, manusia dapat memiliki ilmu pengetahuan sebagai bekal dan modal dasar bagi manusia. Islam menuntut dan memerintahkan manusia untuk menuntut ilmu. Dengan ilmu manusia akan terhindar dari kebodohan, dan mampu menjalani kehodupannya dengan baik. Islam menjadikan ilmu pengetahuan sebagain kebutuhan pokok yang harus ditempuh baik melalui jenjang pendidikan formal maupun non formal. Rasulullah SAW bersabda "Menuntut Ilmu adalah kewajiban atas setiap orang Islam laki-laki maupun perempuan (HR. Ibnu Majah). Islam tidak memberi tolerir kepada umatnya untuk buta terhadap ilmu, buta tulis, buta membaca dan lainnya. Karena hal ini akan membawa manusia berada dalam kegelapan selama menjalani kehidupan di dunia terlebih di akhirat.

Ilmu pengetahuan merupakan kebutuhan dasar manusia, sehingga harus dijaga dan dipelihara. Manusia yang menuntut ilmu, memiliki dan mengamalkannya akan memiliki kesempatan yang luas untuk menapaki kehidupan yang lebih bai di dunia. Karenanya, Islam memberi penghargaan kepada orang yang berilmu sebagaimana Rasulullah SAW bersabda "Barangsiapa 
yang menempuh suatu jalan untuk mencari ilmu, maka Allah memudahkan jalan baginya menempuh jalan ke surga. Tidaklah suatu kaum itu berkumpul di rumah Allah dalam rangka membaca kitab Allah, mengkaji kitab Allah itu di antara mereka, melainkan turun kepada mereka ketenangan, mereka diliputi rahmat, dinaungi Malaikat, dan Allah menyebutnyebut mereka di hadapan orang - orang yang ada di sisi-Nya. Barangsiapa yang terlambat mengamalkannya, maka dia tidak segera diputus hubungannya (HR.Abu Dawud dan Tirmidzi).

Penekanan Islam pentingnya menuntut ilmu pengetahuan melalui pendidikan karena sarana untuk mengembangkan kepribadian manusia, penataan perilaku, pengaturan emosional, hubungan peranan manusia dengan dunia ini, serta bagaimana manusia mampu memanfaatkan dunia sehingga mampu meraih tujuan kehidupan sekaligus mengupayakan perwujudannya. Dengan demikian tujuan pendidikan dalam agama, mulai dari jenjang paling rendah sampai jenjang pendidikan tinggi hendaklah sejalan dengan tujuan diturunkannya agama kepada manusia, yaitu membimbing manusia dalam usahanya kesempurnaan dan kebahagiaan hidup (Kaelany, 2005). Akal pikiran akan mengantarkan manusia mampu mengembangkan ilmu pengetahuan dan teknologi, merupakan salah satu faktor yang mengantarkan terciptanya pertumbuhan ekonomi yang berkualitas. Akal akan mampu menghantarkan manusia untuk bekerja dan berkarya, menghasilkan produk baru atau nilai tambah barang yang sudah ada sebagai sumber pendapatan dan pertumbuhan ekonomi suatu negara maupun daerah. Maka menjaga rasionalitas akal merupakan salah satu syarat untuk terciptanya pertumbuhan ekonomi suatu daerah yang berkualitas.
4. Kualitas Pertumbuhan Ekonomi dan Kebutuhan/Menjaga Keturunan

Menjaga sekaligus memelihara keturunan merupakan suatu kewajiban bagi manusia, karena akan menjadi penentu stabilitas keamanan keluarga, lingkungan maupun negara. Keturunan yang dibina dan dipupuk dengan nilai-nilah akhlakul karimah, akan mampu mengaplikasikannya di kehidupan nyata dengan baik. Terciptanya kedamaian dan ketenangan kehidupan bersumber dari keturunan yang baik dalam rumah tangga sebagai unit terkecil. Generasi yang diwarisi dengan ilmu pengetahuan yang baik, memanfaatkan akalnya secara rasional, mampu memilah yang baik dan tidak baik, yang lurus dan bengkok, yang bersih dan kotor adalah generasi modal dasar suatu bangsa. Generasi inilah yang akan mempercepat proses pembangunan suatu bangsa maupun daerah.

Kehidupan dengan persaingan tengah berlangsung di jaman modern ini, karena tuntutan untuk memenuhi kebutuhan materialistis, manusia secara perlahan telah mengabaikan kualitas keturunannya. Terlihat barbagai perisitiwa sosial yang tengah dihadapi oleh manusia Indonesia termasuk di Nusa Tenggara Barat sebagai pewaris pembangunan bangsa. Anak-anak terlantar, terkontaminasi narkotika (narkoba) dan perbuatan negatif lainnya telah banyak terlihat. Kondisi inilah yang menyebabkan pertumbuhan ekonomi masih berada pada kualitas yang rendah. Anak - anak yang tergolong sebagai penyandang masalah sosial di Nusa Tenggara Barat menunjukkan jumlah yang sangat memperihatinkan selalu berfluktuatif setiah tahun. Hal ini semakin menunjukkan bahwa masa depan keturunan ini semakin suram dan tidak jelas. Narkotika (narkoba) merupakan salah satu komponen yang tergolong dalam kegiatan kriminal. Narkoba dapat merugikan perkembangan dan masa depan anak-anak dan genarasi muda, bahkan dapat merusakan tatanan kehidupan sosial kemasyarakatan yang pada akhirnya akan menggangu stabilitas keamanan dan pertumbuhan ekonomi. 


\section{Elastisitas - Jurnal Ekonomi Pembangunan \\ Vol. 2 No. 2, September 2020}

Menurut Luthf Baraca yang dikutip Mardani (2008) dampak yang terjadi di tengah masyarakat dari penyakit/ketergantungan narkoba antara lain merusak hubungan kekeluargaan, menurunkan kemampuan belajar dan produktivitas kerja secara drastis, sulit membedakan perbuatan baik maupum yang buruk, perubahan prilaku anti sosial (perilaku maladaptif), gangguan kesehatan (fisik dan mental), mempertinggi jumlah kecelakaan lalulintas, tindak kekerasan dan kriminalitas lainnya. Sementara Islam secara tegas melarang manusia untuk mengkonsumsi minuman keras sejenis khamar dan melarang judi. Pengguna Narkoba di NTB meskipun masih dalam jumlah yang relatif sedikit, tetapi hal itu menunjukkan kondisi yang sangat menghawatirkan, karena meningkat dari tahun ke tahun. Lonjakan yang paling banyak terjadi pada tahun 2010 yang semula berjumlah 10 orang pada tahun 2010 melonjak menjadi 158 orang pada tahun 2011. Peningkatan jumlah pengguna narkotika (narkoba) dipastikan membawa dampak negatif terhadap pelaku maupun lingkungannya. Lebih rincinya pengguna narkoba di NTB dapat dilihat berikut.

Tabel 6. Perkembangan Penggunaan Narkotika (Narkoba) Di Provinsi Nusa Tenggara Barat Tahun 2010- 2017.

\begin{tabular}{|c|c|c|c|}
\hline Tahun & Pengguna Narkotika (Orang) & Perubahan & Pertumbuhan (\%) \\
\hline 2010 & 10 & 0 & 0 \\
\hline 2011 & 158 & 148 & 1480,00 \\
\hline 2012 & 163 & 5 & 3,16 \\
\hline 2013 & 174 & 11 & 6,75 \\
\hline 2014 & 163 & -11 & $-6,32$ \\
\hline 2015 & 238 & 75 & 46,01 \\
\hline 2016 & 210 & -28 & $-11,76$ \\
\hline 2017 & 244 & 34 & 16,19 \\
\hline Jumlah & 1370 & 234 & 1534,03 \\
\hline Rata-rata & 152 & 26,00 & 170,45 \\
\hline
\end{tabular}

Sumber : RPJMD Tahun 2013- 2018 dan 2018 - 2023, diolah.

Terlihat bahwa pengguna Narkoba meskipun berfluktuatif setiap tahun tetapi memberikan indikasi yang sangat menghkhawatirkan bagi perkembangan generasi penerus estafet pembangunan daerah maupun bangsa. Penggunaan narkotika (narkoba) atau sejenisnya dalam Islam tidak mendapat tempat untuk diberikan sebagaimana Allah berfirman : Mereka bertanya kepadamu tentang khamar ${ }^{[136]}$ dan judi. Katakanlah: "Pada keduanya terdapat dosa yang besar dan beberapa manfaat bagi manusia, tetapi dosa keduanya lebih besar dari manfaatnya." Dan mereka bertanya kepadamu apa yang mereka nafkahkan.
Katakanlah: " Yang lebih dari keperluan." Demikianlah Allah menerangkan ayatayat-Nya kepadamu supaya kamu berfikir,(Qs. Al-Bqarah, 219).

Mengkonsumsui minuman keras sejenis narkoba dapat mengganggu pikiran dan kesehatan tubuh, sehingga tidak dapat menjalani kehidupannya dengan baik, Manusia yang sudah terkontaminasi dengan narkoba, jiwanya tidak tenang, pikiranselalu menghayal. Akalnya tidak rasional dan penggunaan hartapun akan habis dipergunakan untuk membeli narkoba. Jika generasi ini terus tumbuh maka dipastikan tidak akan memberi nilai tambah bagi perekonomian, bahkan 
menjadi penyebab tidak berkualitasnya pertumbuhan ekonomi.

\section{Kualitas Pertumbuhan Ekonomi dan Kebutuhan/Menjaga Harta}

Harta merupakan kebutuhan inti bagi manusia, sehingga manusia harus dan wajib memelihara dan menjaganya. Pemeliharaan dan penjagaan terhadap harta harus dimulai dari awal dan cara memperolehnya hingga cara pemanfaatannya. Alokasi harta kekayaan yang dilakukan oleh negara harus mengedepankan prinsip keadilan, di mana setiap warga negara memeliki hak dan kesempatan yang sama untuk menikmati hasil kekayaan negara. Warga negara berhak untuk memperoleh kehidupan yang layak dari hasil kekayaan negara serta rakyat wajib untuk merasakan hasil pembangunan yang diperoleh dari harta kekayaan negara. Kepemilikan harta secara individu, juga secara jelas telah diatur oleh agama Islam. Harta memiliki berbagai fungsi dan peranan salah satunya sebagai sarana untuk mencapai kemaslahatan sosial. Harta yang dimanahkan kepada manusia harus diatur dan ditata serta dialokasiskan untuk kepentingan dan kemaslahatan bersama (sosial).

Islam telah memberikan aturan yang jelas tentang penyaluran harta baik berupa perintah wajib maupun sunah,. Hal ini dimaksudkan agar tidak terjadi kertidakadilan dan ketimpangan dalam kehidupan bermasyarakat. Petintah wajib adalah zakat bagi yang memiliki harta melebihi standar minimal (nishab) dan sedekah maupun bentuk lainnya bagi yang belum mempunyai nishab. Perintah zakat sebagai kewajiban, telah ditentukan pula oleh Al-Qur'an orang - orang yang berhak menerimanya di antaranya adalah fakir dan miskin. Penekanan Islam terhadap fakir dan miskin, karena ada dampak yang ditimbulkan bila kefakiran dan kemiskinan masih ada di dalam lingkungan masyarakat.

Islam dalam alokasi harta telah memberikan kepada seseorang harta yang banyak dan ada yang sedikit. Hal ini dilalukan karena Islam telah mengalokasikan harta kepada manusia sesuai dengan kemampuan dan kebutuhannya. Firman Allah SWT dalam surat Saba' ayat 36 : 'Katakanlah: "Sesungguhnya Tuhanku melapangkan rezki bagi siapa yang dikehendaki-Nya dan menyempitkan (bagi siapa yang dikehendaki-Nya). akan tetapi kebanyakan manusia tidak mengetahui." Alokasi harta yang berbeda ini telah menjadi sunnatullah. Allah SWT dengan Kamahatahuan-Nya, telah memberi petunjuk kepada manusia, bahwa jika Allah SWT memberikan kekayaan kepada semua manusia, maka mereka akan melampaui batas, sebaliknya jika Allah SWT memberikan kemiskinan kepada semua manusia, maka mereka akan hancur. Berkenaan dengan hal ini Rasulullah SAW telah bersabda yang artinya "Sesungguhnya bagi setiap umat itu ada fitnah, dan fitnah bagi umatku adalah harta"(HR.At-Tirmidzi). Di dalam harta yang dimiliki oleh orang kaya, terdapat hak orang miskin berupa zakat, sedekah, harta rampasan perang, mendatangkan mereka ketika terjadi pembagian harta warisan (AlAthrasy, 2004). Allah SWT berfirman yang artinya "Katakanlah: "Sesungguhnya Tuhanku melapangkan rezki bagi siapa yang dikehendaki-Nya dan menyempitkan (bagi siapa yang dikehendaki-Nya). akan tetapi kebanyakan manusia tidak mengetahui." Adanya perbedaan rejeki yang diterima oleh setiap orang merupakan pertanda bahwa dalam kehidupan ini manusia harus saling memperhatikan antara satu dengan yang lainnya.

Harta merupakan salah satu sumber dari pertumbuhan dalam ekonomi Islami. Harta yang menumpuk pada sebahagian kecil orang merupakan sumber ketidakadilan dan kecurangan. Oleh karenanya, harta harus didistribusikan sehingga bermakna secara ekonomi maupun secara sosial kemasyarakatan. Salah satu prinsip pertumbuhan ekonomi Islam adalah berimbang, artinya pertumbuhan ekonomi tidak hanya 
berorientasi untuk menciptakan pertumbuhan produksi, namun ditujukan berlandaskan pada keadilan distribusi. Dengan prinsip ini setiap anggota masyarakat memiliki kesempatan yang sama memperoleh kecukupan dalam kehidupan bukan kekurangan (Huda, 2015). Harta yang berada di tangan orangorang kaya, tidak diijinkan untuk ditimbun dan dimonopoli yang membawa dampak tidak terjadi aliran barang kepada orang orang yang membutuhkan.

Pendistribusian harta merupakan salah satu bentuk dari pemeliharaan dan penjagaan terhadap harta itu. Jika harta tidak didistribusikan, dibiarkan menumpuk dengan sia-sia justru menimbulkan kemubajiran. Padahal Islam secara jelas melarang orang untuk berprilaku mubajir, karena sesungguhnya itu adalah perbuatan setan. Membiarkan harta menumpuk, dimanfaatkan pada hal hal yang tidak berguna justru akan membawa masalah dalam perekonomian. Tujuan Islam melarang untuk melakukan penimbunan harta agar manusia terhindar dari perbuatan foya- foya atau boros, menimbulkan sikap pelit dan kikir, rakus dan tamak, serakah yang semuanya merupakan penyakit jiwa yang dapat mengancam keselamatan dalam kehidupan baik di dunia maupun di akhirat.

Maqashiq syariah untuk mencapai kemaslahatan hidup manusia berupa digapainya kebahagiaan dan kemenangan (al-falah) baik di dunia maupun di akhirat. Kebahagiaan tersebut dapat digapai manakala manusia mampu memenuhi menjaga serta memelihara kebutuhan daruriyahnya berupa kebutuhan akan agama (hifdz ad-din), kebutuhan akan jiwa (hifdz an-nafs), kebutuhan akan akal (hifdz Al-Aql), kebutuhan akan keturunan (hifdz an-nasl) dan kebutuhan akan harta (hifdz al-mal). Jika semua kebutuhan ini telah dicapai, maka keselamatan akan diperoleh sekaligus kualitas kehidupan manusia akan meningkat.

\section{KESIMPULAN DAN SARAN Kesimpulan}

Berdasarkan hasil analisis dan pembahasan di atas, dapat ditarik kesimpulan berikut :

1. Pertumbuhan ekonomi berdasarkan harga konstan tahun 2010 termasuk sektor tambang bermula 17,26\% pada tahun 2008 menjadi negatif 4,56\% pada tahun 2018. Pertumbuhan ekonomi berdasarkan harga konstan 2010 tidak termasuk sektor tambang bermula 6,95 $\%$ tahun 2008 turun menjadi 3,08\% pada tahun 2018.

2. Kualitas Pertumbuhan ekonomi provinsi Nusa Tenggara Barat yang dilihat dari :

a. Rata - rata pertumbuhan ekonomi berdasarkan harga konstan tanpa sektor tambang dari tahun 2009 2018 sebesar 5,70 persen. Nilai pertumbuhan ini masih berada di bawah 7 persen sehingga dikatagorikan pertumbuhan ekonomi berkualitas rendah.

b. Hubungan antara pertumbuhan ekonomi dengan kemiskinan tidak searah dan tidak berhubungan kausalitas. Rata - rata persentase penduduk miskin tahun 2008 2018 baru mencapai 14,63 persen. Meskipun persentase penduduk miskin mengalami penurunan, namun pergerakannya melambat. Sejatinya jika pertumbuhan ekonomi meningkat maka jumlah penduduk miskin maupun secara persentase menurun. Hasil kajian ini menunjukkam bahwa ketika pertumbuhan ekonomi menurun, justru secara persentase penduduk miskin juga mengalami penurunan.

c. Hubungan antar pertumbuhan ekonomi dengan pengangguran menunjukkan pola yang sama. Ketika pertumbuhan ekonomi menaik jumlah pengangguran terbuka menaik, tetapi pertumbuhan ekonomi menurun tidak diikuti oleh penurunan pengangguran justru bertambah. Secara rata-rata tingkat 


\section{Elastisitas - Jurnal Ekonomi Pembangunan \\ Vol. 2 No. 2, September 2020}

pengangguran terbuka tahun 2008 -

2018 sebesar 5,13 persen juga menunjukkan angka yang sama dengan pertumbuhan ekonomi. Dengan demikian pertumbuhan ekonomi hanya mampu menurunkan jumlah pengangguran terbuka pada angka yang tidak terlalu tinggi.

3. Pertumbuhan ekonomi yang tergolong dalam kualitas rendah berdampak pula terhadap penerapan nilai-nilai ajaran agama. Dikaitkan dengan maqashid syariah dapat dilihat dari berbagai aspek berikut :

a. Dilihat dari dimensi kebutuhan dan menjaga agama, pertumbuhan ekonomi belum mampu merubah prilaku manusia. Indikator yang dipergunakan adalah masih banyaknya oknum-oknum abdi negara yang melakukan pelanggaran terhadap ajaran agama, yang melakukan korupsi. Pelaku korupsi di daerah Nusa Tenggara Barat berada dalam keadaan yang cukup memprihatinkan.

b. Dilihat dari kebutuhan dan menjaga jiwa, indikator yang digunakan adalah sikap malas. Masih adanya penduduk yang menganggur mengindikasikan bahwa masyarakat tersebut tergolong malas dalam memanfaatkan potensi yang ada di dalam dirinya. Islam tidak memberikan toleransi terhadap pengangguran karena membawa dampak yang luas terhadao stabilitas sosial kemasyarakatan.

c. Dilihat dari kebutuhan dan menjaga ilmu, kualitas manusia dilihat dari kemampuannya membaca dan menulis. Hasil kajian ini menunjukkan manusia sangat membutuhkan ilmu pengetahuan, sehingga Angka Melek Huruf sudah mencapai 85 persen dan masih 15 persen tergolong sebagai buta huruf. d. Dilihat dari kebutuhan dan menjaga keturunan, pertumbuhan ekonomi belum mampu sepenuhnya menurunkan angka kriminilitas yang terjadi di tengah-tengah masyarakat. Salah satu indikator yang dipergunakan dalam kajian ini adalah penggunaan narkoba. Hasil kajian ini menunjukkan bahwa penggunaan narkoba berada dalam kondisi yang sangat memprihatinkan karena akan merusak keturunan (generasi) pewaris pembangunan bangsa.

e. Dilihat dari kebutuhan dan menjaga harta, pertumbuhan ekonomi belum sepenuhnya mampu mewujudkan pengentasan kemiskinan. Persentase kemiskinan di NTB masih berada pada level 14 persen. Dalam hal ini, khususnya umat Islam belum mendisrtribusikan hartanya dengan baik yaitu zakat sebagai kewajiban utama. Penerimaan zakat masih relatif kecil dibanding dengan potensi zakat yang ada. Kehidupan masyarakat sudah tampak mengarah pada hal - hal yang lebih materialistis, sehingga distribusi harta belum berjalan sepenuhnya.

\section{Saran - saran}

Berdasarkan hasil kajian adan analisis dan kesimpulan di atas, dapat diberikan saran-saraa sebagai berikut.

1. Pemerintah provinsi Nusa Tenggara Barat harus terus mengeluarkan kebijakan yang berkenaan peningkatan nilai tambah pada setiap lapangan usaha. Kebijakan bersifat ekspansi dan intensifikasi serta diversifikasi usaha merupakan sumber peningkatan nilai tambah yang dapat menghasilkan pertumbuhan ekonomi yang tinggi.

2. Upaya mewujudkan pertumbuhan ekonomi berkualitas, peningkatan jumlah lapangan kerja, meningkatkan nilai upah minimum akan berdampak pada peningkatan daya beli sehingga 
secara perlahan pengangguran dan kemiskinan dapat dikurangi.

3. Mengedepankan nilai - nilai akhlaq bagi setiap penduduk, terutama dalam melakukan aktivitas ekonomi. Aktivitas ekonomi harus didasarkan pada ajaran agama yang memiliki kitab suci sebagai rujukan dalam melakukan berbagai langkah dan aktivitas.

\section{REFERENSI}

Arsyad, Lincolin. 2010, Ekonomi Pembangunan, UPP STIM YKPN, Yogyakarta.

Badrudin, Rudy, 2012, Ekonomi Otonomi Daerah, UPP STIM YKPN, Yogyakarta.

Bappeda NTB, 2012. NTB Bersaaing Ikhtiar dan Fakta, 2009 - 2011, Mataram.

Chapra, M. Umer, 2010, Epistomologi Ilmu Ekonomi Islam, Penerjemah Ihkwan Abidin Basri, Aqwam. Solo. , 2011, Visi Islam

Dalam Pembangunan Ekonomi Menurut Maqashid Asy-Syariah, Penerjemah Ihkwan Abidin Basri, Al-Hambra,Solo.

Fauzia, Ika Yunia dan Abdul Kadir Riyadi. 2014. Prinsip-Prinsip Dasar Ekonomi Islam Perspektif Maqashid AlSyariah. Kencana PrenadaMedia Group, Jakarta.

Firmanzah, (tt) "Pertumbuhan, Ekonomi Berkualitas". http// www.neraca.co.id/ article/ 38452/ Pertmbuhan Berkualitas

Huda, Nurul, dkk, 2015. Ekonomi Pembangunan Islam, Prenada MediaGroup, Jakarta.
Kaelany, 2005. Islam dan Aspek- Aspek Kemasyarakatan. Edisi Kedua, Bumi Aksara, Jakarta.

Kuncoro, Mudradjat, 2010. Ekonomika Pembangunan Masalah, Kebijakan dan Politik Ed. 5. Erlangga, Yogyakarta.

Maipita, Indra. 2014. Mengukur Kemiskinan Dan Distribusi Pendapatan. UPP STIM YKPM, Yogyakarta.

Mardani, 2008. Penyalahgunaan Narkoba Dalam Perspektif Hukum Islam dan Hukum Pidana Naasional. Radjawali Pers, Jakarta.

Prasetyo, Eko, 2008. "The Quality of Growth : Peran Teknologi Dan Investasi Human Capital Sebagai Pemacu Pertumbuhan Ekonomi Berkualitas". JEJAK, Volume 1, Nomor 1 September 2008.

Stamboel, Kemal A. 2012, Panggilan Keberpihakan Strategi Mengakhiri Kemiskinan Di Indonesia, Kompas Gramedia, Jakarta.

Tambunan, Tulus Th. 2014, Perekonomian Indonesia, Ghalia Indonesia. 